\title{
ADMINISTRATIVE SUPERVISION OF LOCAL SELF- -GOVERNMENT IN THE BALTIC STATES: A COMPARATIVE VIEW
}

\author{
Violeta KiURIENĒ \\ Department of Public Administration, \\ Faculty of Social Sciences, Šiauliai University, \\ Architektu st. 1, LT-78366, Šiauliai, Lithuania \\ E-mail address: v.kiuriene@gmail.com
}

\begin{abstract}
The article analyses models of administrative supervision of local self-government in the Baltic States (Latvia, Lithuania, Estonia) highlighting the advantages and disadvantages of these models. The research done in this article defines the theoretical concept of administrative supervision of local self-government; gives an overview of the legislative framework underpining the key administrative supervision bodies of local self-government in the Baltic States; discusses the issue of legal regulation and the present state of administrative supervision over local self-government units in the Baltic States; gives some theoretical and practical suggestions to develop this field in the Baltic States.

The research methods employed in preparation of this article are theoretical methods of analysis of scientific literature and sources, legal acts and documents as well as comparative and logical analysis, induction and generalisation. Three Baltic States similar in their area, number of inhabitants, and governmental peculiarities have been chosen for the analysis.
\end{abstract}

Keywords: Administrative Supervision, the Baltic States, Local Self-Government

\section{INTRODUCTION}

Public governance changes worldwide, across Europe as well as in Lithuania have direct effects on local self-government. Municipal bodies are public governance institutions that are the closest to people, therefore the local level of governance is very favourable for development of public governance. Implementation of changes in public governance on this level is accompanied by resistance from municipal institutions to changes in the established procedures. Reforming the context of Simon's dichotomy of efficiency and democratic governance Yehezkel Dror (2004, p. 15) maintains that managerial efforts to seek efficiency still confront the fundamental tasks for democratisation of governance, that is, the interests of citizens and their groups who, in the new public governance, seek greater involvement in decision-making. Their involvement, however, is usually restricted to voting and electing the true, actual decision-makers. It is the local and not national level that allows for the easiest inclusion of the public in governance and decision-making. 
The local level is more suitable for interaction with business representatives, various social groups etc. Here the most common elements of public governance include new forms of inclusion of the public in governance, inclusion of local associations, citizens and private partners into local politics (Lazauskiene, 2013, p. 253).

To stimulate broader application and development of the new public governance the state institutions in charge of making laws and other pieces of legislation (parliaments, governments, ministries) strive to emphasize in the newly passed legal acts the importance of development of democratic processes, understanding and dealing with various problems of the society. Public bodies that make laws and other legal acts provide in the legal acts for various strategic structural reforms, institutionalise the strategic goals of the central and local government, market processes, civil society, and rule of law. Thereby, by making new laws or amending the current ones the public bodies aim at new, much higher qualitative parameters of the new public governance. In other words, today, just as previously, the practice of public governance has nothing more steady than changes and reforms (Kettl, Fesler, 2009, p. 113).

To ensure democratic processes in a state the changes in public governance must take place on both state and local self-government levels. However, it is not uncommon for local self-government bodies to be interested in (without ever admitting that) keeping the current procedures and regulations, backing this by an argument that the current situation is the best for the residents of that municipality.

The concept of "self-governance" supposes the criterion of "governing self", which in context of local self-government is very often emphasized and brought above the other principles of local self-government. Any intervention in the activities and decision-making process of local self-government bodies is very often regarded by the very local self-government bodies as violation of rights of local self-government. Yet nobody could deny that local self-government level is often regarded as a place where non legitimate decisions directly affecting the interests of residents of municipalities are made. Various corrupt practices at local self-governance bodies are also discussed often. Law-making institutions (parliaments) and national executive institutions (governments) often make decisions and pass laws that are necessary and expected by society to solve the problems important for the public, particularly those related to provision of various services on the self-government level or reduction of red tape on both business entities and citizens. Paradoxical though it may seem, local self-governance bodies are reluctant to apply laws or decisions made by the national executive power, arguing that they cannot do so because of lack of financial or human resources or suitable infrastructure etc. The weirdest reason given by local self-governance bodies in the effort to justify the non-application of laws or decisions made by national executive power is unawareness of such legal acts having been passed.

In such situations public bodies empowered by the Constitution and (or) the laws to supervise and control the local self-government bodies help to protect the legitimate interests and rights of the state, the public, and individuals residing in municipalities. The purpose of these bodies is to supervise and control, within the scope provided by the Constitution and (or) laws, the local self-government 
bodies and the legitimacy of their activities and decisions they make. Democratic states have many such supervisory bodies, with different functions, but it must be admitted that the theory of public governance clearly lacks deep analysis and generalisation of the competences, rights and obligations of the bodies doing control and supervision as well as the drawbacks and achievements in their activities. It is usually declared that control and supervision is incompatible with the principle of local self-government, that these two definitions are the remains of the traditional, Weberian public governance. It should be noted, however, that public governance cannot be mechanically divided into stages: public administration stage, new public management, and new public governance. Such division into stages is relative, because elements of paradigm of each stage exist (in different forms) in the stage of the new public governance as well.

After restoration of independence in Lithuania some members of society express their views from time to time that the present concept and system of administrative supervision of local self-government in Lithuania is unsuitable, in conflict with the principles of a democratic state, too restrictive on local self-government, and therefore it should be either abolished or reformed. The Offices of the Government Representatives in the Counties - the main offices implementing administrative supervision of local self-government in Lithuania - were discontinued in 1996 with delegation of their functions to County Governors. However, in 1998 the Constitutional Court of the Republic of Lithuania (1998) ruled that the institute of administrative supervision of local self-government is provided for in the toplevel legal act of the state - the Constitution, therefore abolition of the Offices of the Government Representatives in the Counties is unconstitutional. In addition, the Constitutional Court declared that merging of the independent constitutional institute of administrative supervision of activities of local self-government with another institute, which resulted in direct incorporation of local self-government into local governance, is in conflict with the Constitution of the Republic of Lithuania, therefore supervision of legitimacy of activities of local self-government could not be delegated to County Governor. Consequently, in the light of this ruling, the Offices of the Government Representatives in the Counties could be abolished only by amending the Constitution of the Republic of Lithuania. However, in context of changes in public governance possibilities to improve this institute at the statutory level can be sought. This necessitates examination of the institutes of administrative supervision of local self-government, which exist in states similar to Lithuania. Accordingly, countries neighbouring Lithuania and similar in area, number of people, and governance - The Baltic states of Latvia and Estonia - have been selected for the research and the local government administrative supervision model existing in these countries has been examined.

It must be noted that there are only scarce and fragmentary pieces of research into administrative supervision of local self-government. The academic study Local Government in the Members States of the European Union: a Comparative Legal Perspective (2012) provides a fragmentary description of administrative supervision of local governments: the model used in Latvia is briefly discussed by Inga Vilka, the model used in Lithuania is discussed by Diana Saparniene and Aiste 
Lazauskiene, and the model used in Estonia - by Sulev Maeltsemees. In Estonia, the model of administrative supervision of local governments has been analysed by Raivo Linnas (2007, 2009). In Lithuania this model has been investigated by Audrius Bakaveckas (2004, 2006, 2007), Arvydas Andruskevicius (2004, 2008), Violeta Kiuriene $(2013,2014)$.

The research aim is to analyse the models of administrative supervision of local self-government in the Baltic States highlighting the advantages and disadvantages of these models.

The research methods employed in preparation of this article are theoretical methods of analysis of scientific literature and sources, legal acts and documents as well as comparative and logical analysis, induction, and generalisation. Three Baltic States (Latvia, Lithuania, and Estonia) similar in their area, number of inhabitants, and governmental peculiarities have been chosen for the analysis.

\section{CONCEPT OF ADMINISTRATIVE SUPERVISION OF LOCAL SELF-GOVERNEMENT}

Abundance of norms of institute of regulation of control relations is shown by a great variety of control activities and its subjects: administrative supervision of local self-government, control performed by police and other ministerial bodies, supervision and control of provision of public services, enforcement of implementation of administrative decisions, enforcement of implementation of special laws.

According to A. Andruskevicius (2004), public governance is impossible without control activities by officials of governmental bodies: inspections, revisions, audits, assignment implementation control or, for instance, administrative supervision and prevention operations. Enforcement of laws and other regulatory enactments depends on administrative supervision, audit, prevention, and other actions of administrative control. According to A. Andruskevicius (2008), these actions are taken to determine if citizens, legal persons, and public administration entities act precisely in accordance with the law.

A. Bakaveckas (2012) claims that public administration entities must not only implement laws and other legal acts, but also monitor if other entities follow the principle of legitimacy. This function can be called administrative supervision.

Raimundas Kalesnykas (2005) defines administrative supervision as special activities of state-authorised public administration bodies, which are aimed at controlling and checking adherence of organizationally non-subordinate public and other enterprises, institutions, organisations, and citizens to special rules (instructions, procedures) obligatory for all and provided in laws and other pieces of legislation.

A. Bakaveckas (2012) also proposes a similar definition of administrative supervision: administrative supervision is checking by authorised public governance (administration) bodies of adherence to and fulfilment of statutory requirements by organizationally non-subordinate subjects of administrative law in running activities of respective types. 
Some scientists view administrative supervision as part of the state supervision that includes constitutional supervision, supervision by public prosecutors, and judicial supervision. The same scientists point out that in legal literature administrative supervision is described as a type of public administration control because it includes checks on activities of persons. In addition, they support the opinion that administrative supervision is an individual method to ensure legitimacy in public administration.

Bekkers and Vincent Homburg (2002) describe administrative supervision as a form of interaction which is aimed at improvement of political accountability among politicians and policy pursuers.

In the opinion of A. Andruskevicius (2004), administrative supervision is exercised to achieve multiple aims:

- to receive information on whether subjects of law do not violate law and procedures established in administrative regulation enactments;

- to create preconditions that would prevent administrative violations and other breakings of law.

Administrative supervision (control) is certain actions and procedures that help local governments and their bodies to exercise their rights and powers without violating the law (World Bank, 2008).

According to A. Bakaveckas (2012, p. 315), administrative supervision serves two functions:

- helps with forecasting and alerting of occurrence of adverse effects on society and stopping such effects;

- administrative coercion measures are imposed for violations made, they serve preventive and disciplinary functions.

There are two models of supervision and control of activities of local self-governments: administrative supervision and judicial supervision (Puskorius, 2002). In the countries with a continental law system the administrative supervision of activities of local self-governments prevails.

Arvydas Andruskevicius and Laura Paskevicienè (2011) emphasize that as a form of control over public administration the administrative supervision of local self-government is primarily characterised by this function performed by the Government.

The principle of supervision calls for supervision by the national government over activities of local self-governance institutions. There are three main objectives in supervision over activities of local self-governments: to ensure adherence to legitimacy and constitutional principles, to monitor if local self-governments timely perform their functions and if they perform them at all, and to make sure that activities of local self-governments are reasonable.

Ieva Deviatnikovaite (2009) emphasizes that while administrational bodies of local self-government must obey laws and the Government decisions in making their decisions, these bodies are not under direct authority of the bodies of the executive power. Neither the Government nor other bodies of the executive power are in power to cancel the decisions made by the administrational bodies of local self-government: these can be overturned by courts only.

Generalising the conception of administrative supervision a few major aspects can be named: administrative supervision is the function of the executive power; it 
is intended for control over organisationally insubordinate entities; bodies performing administrative supervision have certain powers towards the entities under control. Administrative supervision of local self-government is the function of the national executive power.

\section{ADMINISTRATIVE SUPERVISION OF LOCAL SELF-GOVERNMENT IN THE CONSTITUTIONS OF THE BALTIC STATES}

One of main conditions of the implementation of good governance principles in public administration is the rule of law. This principle ensures that local authorities abide by the law and judicial decisions; rules and regulations are adopted in accordance with procedures provided by the law and are enforced impartially.

Local self-government institutions like the institutions of state public administration have to follow the Constitution and the laws both in the enacting legal acts and in their daily work. Such attitude is based in the conception of local self-government in the main legal acts: The European Charter of Local Self-Government, Constitutions and laws.

In the European Charter of Local Self-Government the local self-government is defined so that, the local authorities, within the limits of the law, have a right and the ability to regulate and manage a substantial share of public affairs under their own responsibility and in the interests of the local population.

Analysis of the Constitutions of the Baltic States (see table 1) reveals that Constitutions of Lithuania and Estonia have separate chapters dedicated to the concept and main principles of functioning of local self-governance (Chapter X, Local Self-Government and Governance in the Constitution of the Republic of Lithuania and Chapter XIV, Local Government in the Constitution of the Republic of Estonia) thereby establishing the principles for functioning of local self-government in these countries by a top-level legal act - the Constitution. Meanwhile the Latvian Constitution contains only fragmentary references to local self-government, the principles of its functioning are not regulated in greater detail. It is not enough to conclude that local self-government principles are recognized in the Constitution of the Republic of Latvia (Vilka, 2012, p. 368).

Tab. 1. Concepts of local self-government in the Baltic States Constitutions

\begin{tabular}{|l|l|l|}
\hline Country & Article & \multicolumn{1}{c|}{ Constitution about local self-government } \\
\hline Latvia & 101 & $\begin{array}{l}\text { Every citizen of Latvia has the right, as provided for by law, to participate in the } \\
\text { work of the State and of local government, and to hold a position in the civil } \\
\text { service. Local governments shall be elected by Latvian citizens and citizens } \\
\text { of the European Union who permanently reside in Latvia. Every citizen of } \\
\text { the European Union who permanently resides in Latvia has the right, } a s \\
\text { provided by law, to participate in the work of local governments. The working } \\
\text { language of local governments is the Latvian language. }\end{array}$ \\
\cline { 2 - 4 } 104 & $\begin{array}{l}\text { Everyone has the right to address submissions to State or local government } \\
\text { institutions and to receive a materially responsive reply. Everyone has the } \\
\text { right to receive a reply in the Latvian language. }\end{array}$ \\
\hline
\end{tabular}




\begin{tabular}{|c|c|c|}
\hline \multirow[t]{5}{*}{ Lithuania } & 119 & $\begin{array}{l}\text { The right to self-government shall be guaranteed to administrative units of } \\
\text { the territory of the State, which are provided for by law. It shal be implemented } \\
\text { through corresponding municipal councils. } \\
\text { The members of municipal councils shall be elected for a four-year term, } \\
\text { as provided for by law, from among citizens of the Republic of Lithuania and } \\
\text { other permanent residents of the administrative unit by the citizens of the } \\
\text { Republic of Lithuania and other permanent residents of the administrative } \\
\text { unit, on the basis of universal, equal and direct suffrage by secret ballot. } \\
\text { The procedure for the organisation and activities of self-government } \\
\text { institutions shall be established by law. } \\
\text { For the direct implementation of the laws of the Republic of Lithuania, the decisions } \\
\text { of the Government and the municipal council, the municipal council shall form } \\
\text { executive bodies accountable to it. }\end{array}$ \\
\hline & 120 & $\begin{array}{l}\text { The State shall support municipalities. } \\
\text { Municipalities shall act freely and independently within their competence } \\
\text { defined by the Constitution and laws. }\end{array}$ \\
\hline & 121 & $\begin{array}{l}\text { Municipalities shall draft and approve their budget } \\
\text { Municipal councils shall have the right, within the limits and according to the } \\
\text { procedure provided for by law, to establish local levies; municipal councils may } \\
\text { provide for tax and levy concessions at the expense of their own budget. }\end{array}$ \\
\hline & 123 & $\begin{array}{l}\text { The observance oh the Constitution and the laws as well as the execution of decisions } \\
\text { of the Government by municipalities shall be supervised by the representatives } \\
\text { appointed by the Government. } \\
\text { The powers of the Government representative and the procedure of their execution } \\
\text { shall be established by law. } \\
\text { In cases and according to the procedure provided for by law, the Seimas may } \\
\text { temporarily introduce direct rule in the territory of a municipality. }\end{array}$ \\
\hline & 124 & $\begin{array}{l}\text { Acts or actions of municipal councils as well as of their executive bodies } \\
\text { and officials which violate the rights of citizens and organisations may be } \\
\text { appealed in court. }\end{array}$ \\
\hline \multirow[t]{5}{*}{ Estonia } & 154 & $\begin{array}{l}\text { All local issues shall be resolved and managed by local governments, which } \\
\text { shall operate independently pursuant to law. } \\
\text { Duties may be imposed on a local government only pursuant to law or by } \\
\text { agreement with the local government. Expenditure related to duties of the state } \\
\text { imposed by law on a local government shall be funded from the state budget. }\end{array}$ \\
\hline & 155 & $\begin{array}{l}\text { Local governments are rural municipalities and cities. } \\
\text { Other local governments may be formed on the bases of and pursuant to } \\
\text { procedure provided by law. }\end{array}$ \\
\hline & 156 & $\begin{array}{l}\text { In elections to local government councils, persons who reside permanently } \\
\text { in the territory of the local government and have attained eighteen years of } \\
\text { age have the right to vote, under conditions prescribed by law. }\end{array}$ \\
\hline & 157 & $\begin{array}{l}\text { A local government shall have an independent budget for which the bases } \\
\text { and procedure for drafting shall be provided by law. }\end{array}$ \\
\hline & 160 & $\begin{array}{l}\text { The administration of local governments and the supervision of their activities shall } \\
\text { be provided by law. }\end{array}$ \\
\hline
\end{tabular}

Source: author concluded on the basis of the Constitution of the Republic of Lithuania, the Constitution of the Republic of Latvia, the Constitution of the Republic of Lithuania.

Valid concepts of local self-government in Lithuania and in Estonia are identical to the conception given in the European Charter of Local Self-Government. Such content of local self-goverment corresponds to the idea of good governance and the concept of the rule of law. In the rule of law the local self-government 
institutions must adopt such administrative acts, by which the civic initiatives, the progress of social and economy of the state, municipality, the preparation of constructive reforms in every possible way would be encouraged. Thus the administrative decisions of public character adopted by the state servants cannot violate the constitutional human rights and freedoms and must corespond the public requirements. The administrative acts are the essence of administrative right, a special public administrative field in the implementation the functions of government and a special kind of public administrative process.

In the preamble of the Constitution of the Republic of Lithuania (1992) is declared the objective of open, just and harmonious civil society and state under the rule of law. The preamble of the Constitution of the Republic of Estonia (1992) also declares that Estonia is founded on liberty, justice and law. Meanwhile the Constitution of Latvia (1922) does not provide for administrative supervision of municipalities.

The European Charter of Local Self-Government (1985) provides the principle of administrative supervision of local authorities' activities. It states that:

- $\quad$ any administrative supervision of local authorities may only be exercised according to such procedures and in such cases as are provided for by the Constitution or by statute;

- $\quad$ any administrative supervision of the activities of the local authorities shall normally aim only at ensuring compliance with the law and with constitutional principles. Administrative supervision may however be exercised with regard to expediency by higher-level authorities in respect of tasks the execution of which is delegated to local authorities;

- administrative supervision of local authorities shall be exercised in such a way as to ensure that the intervention of the controlling authority is kept in proportion to the importance of the interests which it is intended to protect.

Analysis of the Constitutions of the Baltic States reveals that the Constitutions of Lithuania and Estonia establish the principle of administrative supervision of municipalities.

The Constitution of the Republic of Lithuania specifies that the observance of the Constitution and the laws as well as the execution of decisions of the Government by municipalities shall be supervised by the Representatives appointed by the Government. The Constitution of the Republic of Lithuania also declares that the powers of the Government Representative and the procedure of their execution shall be established by law. The similar attitude is embeded in the Constitution of the Republic of Estonia, which declared that the administration of local governments and the supervision of their activities shall be provided by law. Meanwhile the Constitution of Latvia does not provide for administrative supervision of municipalities.

Analysis of the Constitutions of the Baltic States shows that the Constitutions of Lithuania and Estonia establish the main principles of activities of local selfgovernment, including constitutional provision for the principle of administrative supervision of municipalities. The Constitution of Latvia has only fragmentary references to local self-governance, and not even fragmentary references to the principle of administrative supervision of municipalities. The European Charter 
of Local Self-government allows establishment of the principle of administrative supervision of municipalities in the national law, but establishment of this principle in the Constitutions of the countries gives local self-government more guarantees and clearer prospects regarding application of this principle to local self-government, because amendment of the Constitutions is usually much more complicated procedure than amendment of laws.

\section{ADMINISTRATIVE SUPERVISION OF LOCAL SELF-GOVERNMENT IN THE MAIN LEGAL ACTS, REGULATED LOCAL SELF-GOVERNMENT}

In Estonia and in Lithuania the main laws that regulate local self-government and its principles as well as competence, rights, and duties of municipal bodies and relations of these bodies with public bodies generally echo the main principles behind administrative supervision of municipalities laid out in the Charter and Constitutions. In the case of Latvia (considering that these principles are not constitutionally regulated in detail), the Law "On Local Governments" is the principal legal act defining local self-governance and laying the foundation for administrative supervision of municipalities.

Tab. 2. Concepts of local self-government in the main legal acts, regulated local self-government

\begin{tabular}{|l|l|l|}
\hline Country & Legal act & $\begin{array}{l}\text { Concept of local self-government in the main legal acts, regulated } \\
\text { local sel-government }\end{array}$ \\
\hline Latvia & $\begin{array}{l}\text { The Law } \\
\text { "On Local } \\
\text { Governments" }\end{array}$ & $\begin{array}{l}\text { A territorial local authority is a local administration which, } \\
\text { through bodies of representatives elected by citizens - city or } \\
\text { novads council - and authorities and institutions established } \\
\text { by them, ensures the performance of the functions prescribed by law, } \\
\text { as well as the performance of tasks assigned by government according } \\
\text { to the procedures specified by law, and local government voluntary } \\
\text { initiatives, observing the interests of the State and of residents of } \\
\text { the said administrative territory. }\end{array}$ \\
\hline Lithuania & $\begin{array}{l}\text { The Republic } \\
\text { of Lithuania } \\
\text { Law on the } \\
\text { Local Self- } \\
\text { Government }\end{array}$ & $\begin{array}{l}\text { Local Self-Government means the right and actual power of the } \\
\text { institutions of a local government which is elected by the residents } \\
\text { of an administrative unit of the territory of the Republic of Lithuania, } \\
\text { to freely and independently on their own responsibility regulate and } \\
\text { manage public affairs and meet the needs of local residents according } \\
\text { to the Constitution and laws of the Republic of Lithuania. }\end{array}$ \\
\hline Estonia & $\begin{array}{l}\text { The Local } \\
\text { Government } \\
\text { Organisation } \\
\text { Act }\end{array}$ & $\begin{array}{l}\text { Local government is the right, authority and duty of the } \\
\text { democratically formed bodies of power of a local government } \\
\text { provided for in the Constitution, a rural municipality or city, to } \\
\text { independently organise and manage local issues pursuant to law and } \\
\text { based on the legitimate needs and interests of the residents of the rural } \\
\text { municipality or city, and considering the specific development of the } \\
\text { rural municipality or city. }\end{array}$ \\
\hline
\end{tabular}

Source: author concluded on the basis of the Law "On Local Governments", the Republic of Lithuania Law on the Local Self-Government, the Local Government Organisation Act. 
Pursuant to shown legal acts, the autonomy of the local self-government institutions should be treated first of all in light of the main purpose of the state; then afterwards in light of the interests of the local inhabitants and finally in light of the autonomy of local self-government as an end in itself. This particular aspect is very important to remember especially in the case of a politically unitary nation-state (Linnas, 2009, p. 144).

\section{ADMINISTRATIVE SUPERVISION OF LOCAL SELF-GOVERNMENT IN THE MAIN LEGAL ACTS, REGULATED ADMINISTRATIVE SUPERVISION OF LOCAL SELF-GOVERNMENT}

As far as the municipalities act within their own sphere of activity, they are subject to legal supervision. Here legal supervision is restricted to supervising the performance of public law tasks and the obligations of the municipalities as laid down by law and adopted, as well as the legality of their administrative activity. The state may thus not interfere in the exercise of discretion where the municipalities have been given discretion by law and where they exercise this discretion lawfully (Harbich, 2009). Local governments, within the scope of their competence and the law, act in autonomous, but, in implementing delegated state administrative functions and administrative tasks, a local authority represents the state and is then subordinate to the government.

However, where the institutions of municipalities act illegally, the officers, who execute the administrative supervision, must interfere:

In Lithuania that is the Government Representatives in the Counties, whose power, rights and duties, offices are defined by the Law on Administrative Supervision of Local Authorities of the Republic of Lithuania;

In Estonia that is the County Governor. He has the power to supervise the legality of legislation and adjudications of local bodies within his jurisdiction, in the cases and to extent provided by law. His authority provides the Government of the Republic Act;

In Latvia unlawful decisions (resolutions) of a local council, with the exception of resolutions applying to individual legal entities of physical persons, or separate articles in a resolution, may be suspended by the Minister of Environmental Protection and Regional Development. There is a Local Governments Supervision Division of Local Governments Department in the Ministry of Environmental Protection and Regional Development and only five people work in this division.

Analysis of powers shows that the greatest powers in administrative supervision of municipalities belong to the Government Representative in the County in Lithuania. 
Tab. 3. Powers of special institutions doing administrative supervision of local self-governement

\begin{tabular}{|c|c|c|}
\hline $\begin{array}{c}\text { Latvia } \\
\text { (the Minister of } \\
\text { Environmental Protection and } \\
\text { Regional Development) }\end{array}$ & $\begin{array}{c}\text { Lithuania } \\
\text { (The Government } \\
\text { Representative in the } \\
\text { County) }\end{array}$ & $\begin{array}{c}\text { Estonia } \\
\text { (the County Governor) }\end{array}$ \\
\hline $\begin{array}{l}\text { - Substantiated ruling; } \\
\text { - Application to Court. }\end{array}$ & $\begin{array}{l}\text { - Advance supervision } \\
\text { of drafts of legal acts } \\
\text { of municipal collegial } \\
\text { administration entities; } \\
\text { - Reasoned proposal; } \\
\text { - Written request; } \\
\text { - Decree; } \\
\text { - Application to the } \\
\text { Administrative Court } \\
\text { regarding legality of } \\
\text { legal act; } \\
\text { Application to the } \\
\text { Administrative Court } \\
\text { regarding defending } \\
\text { the public interest; } \\
\text { Claim to the Court of } \\
\text { General Jurisdiction } \\
\text { regarding defence of } \\
\text { public interest; } \\
\text { Application to the } \\
\text { Administrative Court } \\
\text { regarding abolition of } \\
\text { legal act or regarding } \\
\text { obligation to execute } \\
\text { the law or decision of } \\
\text { Government. }\end{array}$ & $\begin{array}{l}\text { - Writing proposal; } \\
\text { - Protest to the Administrative } \\
\text { Court; } \\
\text { - Report to the State Audit Office } \\
\text { or to another competent agency. }\end{array}$ \\
\hline
\end{tabular}

Source: concluded by author.

In Lithuania the Representative of the Government exercises administrative supervision of local authorities, i.e. supervises that local authorities act in compliance with the Constitution and laws of the Republic of Lithuania, and carries out decisions of the Government. This officer is the civil servant - the manager of the institution, who is appointed for these duties for four years in the competition way, which is organized by the Government. The Government Representative is subordinated to the Government and accountable to the Prime Minister. A person having a university education and with at least five year's experience of work in the field of public administration, or having the university legal education or the public administration education and with at least three year's experience of work in the field of public administration may be appointed as Government Representative.

The Law on Administrative Supervision of Local Authorities of the Republic of Lithuania states that the Government assigns one Representative of the Government to each county. Each Representative of the Government has an Office. This Office helps the Government Representative to implement his authorities and 
rights. The Government establishes the Office of the Government Representative and the amount of state officers. Number of staff in this office varies from 3 to 9 . As can be seen from the submitted table, the ambits of administrative supervision of municipalities executed by the Government Representatives are very large. The number of civil servants working in the offices of the Government Representatives in the Counties is very small compared to the amount of supervised municipalities and to the number of people living in these municipalities. The municipal entities adopt legal acts, concerning the people living in these municipalities. As we know, not always are the legal acts adopted by municipal entities lawful. The Government Representative in the County, with the intention to defend the interests of municipality's people and of state's, must react to the violation made by the municipal entities immediately.

Only in Lithuania the Government Representative in the County performs the advance supervision of drafts of legal acts drawn up by municipal municipal council. This supervision is one of the most important stages of administrative supervision, which allows reduction of the number of illegal acts admitted in the municipalities within the process of legal act admission. According the Law on Administrative Supervision of Local Authorities of the Republic of Lithuania when carrying out the control of draft legal acts, the Government Representative in the County may examine draft legal acts submitted to municipal collegial administration entities for adoption and (or) attend meetings of municipal collegial administration entities and, where appropriate, inform the municipal councillors that the drafts under consideration do not comply with laws or decisions of the Government.

After examination municipalities most of the time have considered to the given remarks of Government Representatives. The indicated contradictions to the legal acts in the drafts can be corrected before the session of municipal council or during the session. In the cases, if municipalities do not consider to the Government Representative's submitted notice regarding drafts legal acts, which do not comply with valid legal acts and admit such legal acts, the Government Representative prepares the presentation for the Municipal Council to abolish the admitted decision. If Municipal Council refuses to fulfill such presentation, the Government Representative appeals to the Court regarding abolition of admitted decision.

According the Law on Administrative Supervision of Local Authorities of the Republic of the Government Representative in the County executes not only supervision of draft legal acts, but also controls, if legal acts adopted by the municipal collegial and non-collegial administration entities do not comply with laws, decisions of Government and other legal acts, related to the implementation of laws, and adopted by the central state administration entities. In this case the main form of implementation of Government Representative's power is written reasoned proposal. These implementation forms exercise also the Minister of Environmental Protection and Regional Development in Latvia and the County Governor in Estonia.

In Latvia the Minister of Environmental Protection and Regional Development can suspend unlawful decisions (resoliutions) of a local council. Within two weeks 
from the receipt of a Minister ruling, the council's chairperson must summon an extraordinary council meeting which must decide whether to withdraw or annul the controversial resolution or to make it comply with the laws and other legal acts in effect. The Minister, then, must be duly notified as to the time and venue of the council meeting. The chairperson of the council has the right to apply to court with an appeal to revoke the instruction of the responsible minister without summoning an extraordinary council meeting. If the council or council's chairperson fails to enact the conditions set by the relevant Minister or fails to apply to court in due time, the illegal resolution or its separate articles will be considered as revoked. The minister publishes this state of facts in an official newspaper (Vilka, 2012, p. 382).

In Estonia if the County Governor finds that legislation of specific application of a local government council or government is in conflict with the Constitution, law or other legislation, he or she may submit a proposal in writing to bring the legislation into conformity with the Constitution, the law or other legislation. If the council or government refuses to bring the legislation into conformity with the Constitution, a law or other legislation the County Governor shall file a protest to Administrative Court.

Only in Lithuania the Government Representative in the County can write written request and decree. When municipal administration entities do not comply with the Constitution and laws, do not execute the decisions of Government, the Government Representatives require, that the Constitution must be followed, the laws implemented, and the decisions of Government executed. In this case the main implementation form of Government Representatives' powers is written request. According the Law on Administrative Supervision of Local Authorities of the Republic of Lithuania the Government Representative in the County can suspend the execution of local self-government institutions legal acts. Decree is definable if the municipal council or another municipal administration entities (Mayor of Municipality, the Director of Administration, Warden and likewise) initiate legal act, by which can be made the illegal and violating the public interest contract or legal act can violate the public interest.

But in Estonia the County Governor can exercise supervision over the legality and purposefulness of the use of state assets in the use or control of local governments. If the County Governor discovers that the local government has possessed or used state assets unlawfully or non-purposefully, he or she shall file a report with the State Audit Office, or with another competent agency. In Lithuania and Latvia these functions are performed by other institutions. But it is not good, because The County Governors in Estonia have a conflict of interest because they serve as a representative and supervisory body of government and represent the interests of local self-government against the state government as well. County governors have to be released from this conflict of interest situation. This means that the tasks of entire, coherent and systemic regional development should be transferred from county governors to the associations of local self-government acting on the territory of the counties in question. The actual administrative capacity of a County Governor in supervising the lawfulness of local government activities is often unsystematic, inconsistent and insufficient (Linnas, 2007, p. 286; 2009, p. 151). 
According R. Linnas (2007, p. 286) a County Governor may be unobjective and politically biased, as the posts of County Governors are allocated according to political affiliation or other political reasons and one's competence is of secondary importance. Furthermore, County Governors are in permanent situation of political pressure and uncertainty because of long-lasting discussions over their role and scope of responsibilities. County Governors used to be seen as respectable representatives of the central government in the regions, but at the moment they are somewhat heads of department of the Ministry of Interior (Linnas, 2009, p. 153).

Generalising, it can be stated that all three Baltic States have institutions doing administrative supervision of local self-government, but it is only in Lithuania that the Constitution and special legal acts provide for supervision of activities of municipalities by specially appointed officials: Government Representatives in the Counties acting under the special law on administrative supervision of municipalities of the Republic of Lithuania. While in Estonia County Governors have additional duties: checking on legitimacy and relevance of use of public assets. Furthermore, the comparative analysis of the institute of administrative supervision of local self-government in the Baltic States reveals that monitoring of legitimacy of all legal acts passed by all municipal bodies is done only in Lithuania. In the course of this monitoring special attention is paid to regulatory enactments, that is, the legal acts with direct influence on all residents of the municipality (such as regulation of waste management, regulation of admissions to educational institutions, pricing of water supply, public transportation, and heat supply services etc). It was found that it is only in Lithuania that local governance bodies are obliged to submit all the legal acts they have passed to the special subjects engaged in administrative supervision of local self-government: Government Representatives in the Counties. Neither Estonian, nor Latvian legislation requires local self-government bodies to do so. In Lithuania Government Representatives in the Counties have great problems verifying legitimacy of all legal acts passed by all municipal bodies as they have very limited human resources (staff number at one service ranges from 3 to 9 civil servants). Yet the problem with administrative supervision and human resources of municipalities in Latvia is even sharper, because the Local Governments Supervision Division of Local Governments Department of the Ministry of Environmental Protection and Regional Development has a staff of only 5 civil servants. This leads to conclusion that attention given to administrative supervision of municipalities in Latvia is particularly scarce.

\section{CONCLUSIONS}

Generalising the conception of administrative supervision a few major aspects can be named: administrative supervision is the function of the executive power; it is intended for control over organisationally insubordinate entities; bodies performing administrative supervision have certain powers towards the entities under control. Administrative supervision of local self-government is the function of the national executive power. 
Valid concepts of local self-government in Lithuania and in Estonia are identical to the conception given in the European Charter of Local Self-Government. Such content of local self-goverment corresponds to the idea of good governance and the concept of the rule of law. The Constitution of Latvia does not provide for administrative supervision of municipalities. Analysis of the Constitutions of the Baltic States shows that Constitutions of Lithuania and Estonia establish the main principles of activities of local self-government, including constitutional provision for the principle of administrative supervision of municipalities. The Constitution of Latvia has only fragmentary references to local self-government, and not even fragmentary references to the principle of administrative supervision of municipalities. The European Charter of Local Self-government allows establishment of the principle of administrative supervision of municipalities in the national law, but establishment of this principle in the Constitutions of the countries gives local self-governance more guarantees and clearer prospects regarding application of this principle to local self-government, because amendment of the Constitutions is usually much more complicated procedure than amendment of laws.

Local governments fulfil the state functions which are assigned to them by law or which arise from a contract between an authorised state body and a specific council. According to the spirit of the Constitution of Lithuania and the Constitution of the Estonia, the central and local governments form a holistic integral organization and the local self-government sector is one particular level of the holistic public administration organization in a state. Hence, the absoliute abstract autonomy of local self-government as an end in itself, without the context of the most important purpose of a nation-state and without the main purpose of local self-government within the state, would not be a relevant object of treatment in actual socio-political life, may be misleading and does not match the paradigm of the European Charter of Local Self-Government as well (Linnas, 2009, p. 144).

In Estonia and in Lithuania the main laws that regulate local self-government and its principles as well as competence, rights, and duties of municipal bodies and relations of these bodies with public bodies generally echo the main principles behind administrative supervision of municipalities laid out in the Charter and Constitutions. In the case of Latvia (considering that these principles are not constitutionally regulated in detail), the Law "On Local Government" is the principal legal act defining local self-governance and laying the foundation for administrative supervision of municipalities. Analysis of the main legal acts, regulated local self-government, shows that the autonomy of the local self-government institutions should be treated first of all in light of the main purpose of the state; then afterwards in light of the interests of the local inhabitants and finally in light of the autonomy of local self-government as an end in itself.

All three Baltic States have institutions doing administrative supervision of local self-government, but it is only in Lithuania that the Constitution and special legal acts provide for supervision of activities of municipalities by specially appointed officials: Government Representatives in the Counties acting under the special law on administrative supervision of municipalities of the Republic of Lithuania. While in Estonia County Governors have additional duties: checking 
on legitimacy and relevance of use of public assets. Furthermore, the comparative analysis of the institute of administrative supervision of local self-government in the Baltic States reveals that monitoring of legitimacy of all legal acts passed by all municipal bodies is done only in Lithuania. In the course of this monitoring special attention is paid to regulatory enactments, that is, the legal acts with direct influence on all residents of the municipality.

Administrative supervision of local self-government is not a purposeless mechanism of coercion against bodies of local self-government. Administrative supervision of local self-government is linked to public interest. On the level of local self-government administrative supervision of local self-government helps to ensure transparency, openness, civic spirit, pluralism, democracy, and absence of corruption at bodies of local self-government and even active operation of non-governmental organisations. These features are in line with the paradigm of the new public governance. Therefore it can be maintained that administrative supervision of local self-government is a public good provided not on competition basis and one of the public administration forms fulfilling the objectives of public governance in order to benefit the public interest: ensuring legitimacy at local self-government.

When improving a system of administrative supervision of local self-government at a specific country it is necessary to consider the tendencies of development of such a system in other countries while maintaining a critical estimation of extent of applicability of experience of the other countries under specific current situation of economic and cultural development of that specific country.

\section{REFERENCES}

Andruškevičius, A. (2004). Administracinès teisés principai ir normu ribos [Administrative Law's Principles and Limits of Norms]. Vilnius: Teisinès informacijos centras.

Andruškevičius, A. (2008). Administraciné teisé [Administrative Law]. Vilnius: Vİ Registrų centro Teisinès informacijos departamentas.

Andruškevičius, A., Paškevičienè, L. (2011). Viešojo administravimo teisiniai pagrindai [Legal Framework of Public Administration]. Vilnius: Registru centras.

Bakaveckas, A. (2004). Savivaldybių administracinè priežiūra: raida, teisinis reglamentavimas ir problemos [Administrative Supervision of Local Self-Government: Evolution, Legal Regulation and Problems]. Jurisprudencija, 57 (49). 24-33.

Bakaveckas, A. (2007). Lietuvos vykdomoji valdžia [Lithuania's Executive Power]. Vilnius: Eugrimas.

Bakaveckas, A. (2012). Administracine teisé: teorija ir praktika [Administrative Law: Theory and Practice]. Vilnius: Mes.

Bekkers, V., Homburg, V. (2002). Administrative supervision and informatikon relationships. Netherlands. Retrieved from http:/ / repub.eur.nl/res/pub/632/BSK006.pdf

Decision of the the Constitutional Court of the Republic of Lithuania (1998). Retrieved from https:/ / www.e-tar.lt/portal/en/legalAct/TAR.2E51ABA808DB

Dror, Y. (2004). Strategic Brain for Central Government. In: M. Potuček (Ed.). The Capacity to Govern in Central and Eastern Europe (pp. 15-27). Bratislava: NISPAcee.

Constitution of the Republic of Latvia (1922). Retrieved from http:/ /www.saeima.lv/en/legislation/ constitution

Constitution of the Republic of Lithuania (1992). Retrieved from http://www3.lrs.lt/home/Konstitucija/Constitution.htm

Constitution of the Republic of Estonia (1992). Retrieved from http://www.president.ee/en/ 
republic-of-estonia/the-constitution

European Charter of Local Self-Government. Retrieved November 03, 2015 from http://conventions. coe.int/Treaty/en/Treaties/Html/122.htm

Government of the Republic Act (1985). Retrieved from http://www.legaltext.ee/text/en/X0007K16. htm

Harbich, J. (2009). State Supervision on Local Government Authorities. Retrieved from http:/ fwww. fu.uni-lj.si/uprava/clanki/Letnik2009/2009-4-December-3-Harbich.pdf

Kalesnykas, R. (2005). Viešojo administravimo teisés aktai [Legal Acts of Public Administration]. In: Lietuvos administracine teisé. Bendroji dalis [Lithuanian Administrative Law] (pp. 483-484). Vilnius: MRU.

Kettl, F. D., Fesler, W. J. (2009). The Politics of Administrative Process. Washington: D. C. CQ Press.

Kiurienè, V. (2013). Administrative Supervision of Local Self-Government as an Expression of the Rule of Law in the Context of Good Governance: the Case of Lithuania. Socialiniai tyrimai, 4 (33). 44-55.

Kiurienè, V. (2013). Lietuvos Respublikos Vyriausybès atstovų apskrityse igaliojimų igyvendinant savivaldybių administracinę priežiūrą analizè: 2008-20012 metai [The Analysis of Implementation Forms of Government Representatives in the Counties of the Republic of Lithuania Implementing Administrative Supervision of Local Self-Government: 2008-2012]. Ekonomika ir vadyba: aktualijos ir perspektyvos, 3(31). 7-21.

Lazauskienè, A. (2013). Vietos savivalda [Local Self-Government]. In: D. Šaparnienė, A. Krupavičius (Eds.). Viešasis valdymas: koncepcijos ir dimensijos [Public Administration: Concepsions and Dimensions] (pp. 253-269). Vilnius: BMK LEIDYKLA.

Linnas, R. (2009). Legal Framework and Present State of External Control and Supervision of Local Self-Government Units in Estonia. Kunnallistieteellinen aikakauskirja, 2. 141-162. Retrieved from file:/ / C:/Users/user/Downloads/Legal+Framework+and+Present+State+of+External+Contro 1+and+Supervision+of+Local+Self-Government+Units.pdf

Maeltsemees, S. (2012). Local Government in Estonia. In: A. Moreno (Ed.). Local Government in the Member States of the European Union: a Comparative Legal Perspective. Madrid: National Institute of Public Administration.

Par pašvaldībām [The Law "On Local Governments"]. Retrieved from http://likumi.lv/doc. php?id=57255

Puškorius, S. (2002). Viešojo sektoriaus instituciju administravimas [Aministration of Public Sector]. Vilnius: Lietuvos Teisės universitetas.

Vilka, I. (2012). Local Government in Latvia. In: A. Moreno (Ed.). Local Government in the Member States of the European Union: a Comparative Legal Perspective. Madrid: National Institute of Public Administration.

World Bank Publications (2008). Decentralization and Local Democracy in the World: First Global Report by United Cities and Local Governments. Retrieved from http://books.google.lt/books $? \mathrm{id}=8 \mathrm{~m} 2 \mathrm{CQeX} 4 \mathrm{EuwC} \&$ printsec $=$ frontcover\&hl=1t\&source=gbs_ge_summary_r\&cad $=0 \# \mathrm{v}=$ onep age\& $q \& \mathrm{f}=$ false 